\title{
Challenges in Italian wine routes: managing stakeholder networks
}

\author{
Ilenia Bregoli Ibregoli@,lincoln.ac.uk (corresponding author), \\ Martin Hingley, University of Lincoln Business School, UK \\ Giacomo Del Chiappa, University of Sassari Department of Economic and Business, Sardinia \\ Valeria Sodano, University of Naples, Federico II, Portici, Italy
}

Dr. Ilenia Bregoli is Lecturer in Marketing at the University of Lincoln (Lincoln Business School), United Kingdom. Her research interests are in destination marketing and management; destination branding studied from the supply-side perspective; experiential marketing in multi-stakeholders environment. She has published articles in the Journal of Travel Research, Tourism Analysis and the International Journal of Tourism Research.

Dr. Martin Hingley is Professor of Strategic Marketing at University of Lincoln (Lincoln Business School), United Kingdom. His major research interests are in food marketing, supply chain management and SME networks. He has presented and published widely in these areas, and also regularly guest edits prestigious academic journals. He has wide-ranging business experience in the international food industry.

Dr. Giacomo Del Chiappa is Assistant Professor of Marketing at the Department of Economics and Business, University of Sassari, Italy, and associate researcher at CRENoS. His research is related to destination governance and branding, consumer behaviour, and digital marketing. He has published articles in several international journals, among the others: Journal of Travel Research, International Journal of Tourism Research, International Journal of Contemporary and Hospitality Management, Current Issues in Tourism, Information Systems and E-Business Management.

Dr. Valeria Sodano is Associate Professor of Agricultural Economics at the University of Naples 'Federico II', Italy. Her major fields of research and teaching are regional development, agricultural marketing, food safety, and supply chain management. She is a Senior Lecturer at the 'Centro per la Formazione in Economia dello Sviluppo Rurale', an Italian leading research institute in the field of economics of development.

\section{Research paper}

\begin{abstract}
Purpose - The aim of this article is to analyse how wine and tourism operators understand the concept of a wine route, in order to determine the impact that definition can have on the extent to which stakeholders working within distinct, but related sectors (namely wine production, tourism, food and hospitality) collaborate with each other and share knowledge.
\end{abstract}

Design/methodology/approach - By adopting the theoretical lens of "boundary objects" (understood as tangible or intangible entities that allow the sharing of meaning to different groups and facilitate collaboration), this article uses a qualitative approach, based on semi-structured interviews of 20 informants working in three different wine routes in Italy. Analysis of data is carried out in order to highlight the similarities and differences between the wine and tourism (including identified associated service) industries.

Findings - Wine routes can be considered boundary objects that, if clearly defined by local stakeholders, can facilitate knowledge sharing and collaboration. Problems in collaboration could be explained by an initial misdefinition by stakeholders of what a wine route and its remit are.

Research limitations - Since the theoretical lens of "boundary objects" was applied for the first time to wine routes and tourism, further research is necessary in order to validate its application. 
Practical implications - It is suggested that managers of wine routes involve all stakeholders in discussions to achieve a common understanding on what a wine route is and its role in the promotion of "place" (geographical context of the wine route). Only if this is done successfully, is it possible to achieve collaboration.

Originality/value of the paper - This article uses the concept of "boundary objects" (a concept traditionally applied to the study of innovation) to the analysis of wine routes, and provides further theoretical and managerial insights concerning networking between wine and tourism sectors, taking a supply-side perspective.

Keywords - wine routes, tourism, place branding, Italy, networks, boundary objects

Acknowledgement - The authors acknowledge the financial contribution by the Fondazione Banco di Sardegna "Lo sviluppo dell'enoturismo in Sardegna: minacce e opportunità" [Wine tourism development in Sardinia: weaknesses and threats] Prot: U820.201.3/AI.744.MGB.

Acknowledgement - The authors are grateful to the anonymous reviewers for their valuable feedback and suggestions which have greatly enhanced the quality of this manuscript. 


\section{Introduction}

Wine tourism has emerged as an important area of tourism in many countries of the world (Hall and Mitchell, 2000). It has been defined as "visitation to vineyards, wineries, wine festivals, and wine shows for which grape and wine tasting and / or experiencing the attributes of a grape and wine region are the prime motivating factors for visitors" (Hall, 1996 cited in Hall and Mitchell, 2000). Research focused on wine tourism has suggested that it can be useful for promoting the economic, social and environmentally sustainable development of rural regions (Alonso and Liu, 2012), as well as for facilitating the interaction between tourists and producers. Similarly to what is said for food tourism (e.g. Presenza and Del Chiappa, 2013), wine tourism has been acknowledged as being a lever to promote the culture, identity and authenticity of national, regional and local areas (Hall and Mitchell, 2000), and to affirm a unique destination brand (Bruwer and Johnson, 2010). Indeed, one of the growing trends in wine tourism has been recognised in "the pairing of wine with high-end food products". (Telfer 2001, p. 25). Furthermore, prior research also shows that visitors may not travel to wineries as their sole intention but rather they tend to visit other attractions or undertake activities different from wine tasting or winery visits, for example, they visit heritage sites and practice sports such as golf (Correia et al., 2004; Carlsen, 2004), thus reinforcing the role of wine tourism as a lever of destination promotion and tourism development.

However, it could be argued that little attention has been devoted in the literature to the connections between wine and other tourism and non tourism-related sectors, with governments and analysts having begun, only recently, to recognise and to encourage stronger collaboration and cooperation amongst these sectors (Hall et al., 2000). This is despite the fact that it is apparent that effective wine tourism development cannot be achieved through relying exclusively on wine producers, given the fact that they tend to have little experience in tourism services and are more focused on wine production and wine marketing (Brás et al, 2010). In Europe, and in many other countries of the world, wine tourism has largely been developed in the form of 'wine routes' (Hall et al., 2000). The term wine route has been defined and analysed in many ways, and through adopting different perspectives, as will be discussed in the following sections. According to Bruwer (2003, p. 424) a wine route is "a tourist route that connects several wine estates and wineries in a given area... This route is characterised by natural attractions (mountains or other scenery), physical attractions (facilities such as wineries on wine estates), vineyards, and roads and markers (signposts) directing the tourist to the individual wine route estate enterprises". However, this definition implies an almost linear guide, rather than something more embracing of wider stakeholders and purpose. Brás et al. (2010, p. 1621) suggest a more encompassing definition of a wine route as "a network of agents in a wine region, whose purpose is to promote regional development by employing strategies that lead to the development of an inclusive regional network which encompasses public and private agents from both sectors of activity (wine and tourism)". In order to facilitate such networking arrangements among public and private stakeholders, specific coordination structures for regional networks have been created, among these, wine routes are certainly the most known.

Despite their importance as an example of network organisation able to enhance and exploit wine tourism development, wine routes can be still considered an underinvestigated area of tourism research, and very few published papers deal with this topic (e.g: Brás et al., 2010; Telfer, 2001). This is particularly true when the context of Italy is considered. Furthermore, even when research does exist and it is aimed at analysing the networking dynamics and structure of wine routes, it tends to focus on considering just wine related businesses (Brás et 
al. 2010; Telfer, 2001), whereas the collaboration between wine and other tourism businesses has always been cited as a key factor for wine tourism development but rarely analysed empirically. This seems to suggest that further theoretical and empirical studies would be useful in order to better define the "boundaries" of wine routes. Academic research defines boundary objects as physical or intangible entities that allow the passing of meaning to people belonging to different groups (such as communities of knowledge or practice) and thus facilitate collaboration (Fox, 2011). This study aims at applying the lens of a "boundary object" in the setting of wine routes, in order to investigate whether they are perceived as a network among wine producers, tourism businesses, associated services and hospitality businesses (Alonso and Liu, 2010). Hence, the study presents and discusses the factors that can facilitate or hinder the collaboration between organisations belonging to the two industries (wine and tourism). Further, it considers whether and to what extent wine routes are used to promote the local area in which the wine route is located, and the local identity. To achieve this aim, a qualitative approach has been adopted based on 20 semi-structured interviews carried out with key stakeholders in wine routes based in three different Italian Regions (Tuscany, Sardinia and Lombardy).

This article is made up of the following sections. A review of literature concerning the factors that affect the development of networks in the wine and tourism industries, and the concept of wine routes will be presented. This section is then followed by a methodological design for an exploratory qualitative approach. In the analysis and discussion section the results from the interviews are presented using the lens of "boundary objects". Finally, with conclusions and recommendations, the arguments are drawn together and limitations, managerial implications and directions for possible future stakeholder-network arrangements and contexts are presented.

\section{Understanding and conceptualisation of wine routes}

It is widely recognised that the link between the wine industry and tourism is evident, with its roots in the history of hospitality industry (Getz, 2000), at least when a demand-side perspective is considered. Consumers often consider wine and culinary experiences as being a prime motivation to travel, select a destination and choose where to stay, or these experiences contribute to consumers' socialising, learning and entertaining; regardless of the main reason that incentivised them to travel (Dodd, 1995).

Based on the work of Martin and Williams (2003), factors affecting wine tourism development can be categorised as internal and external. The internal factors refer to the capability and commitment of local stakeholders to engage in tourism ventures (education, financial resources, competences, networking capability, etc). The external factors refer to policy and macroeconomic forces that create a favourable environment for wine tourism to succeed in terms of: regional infrastructure, preservation of natural environment, training local stakeholders to guarantee appropriate level of professionalism, the networking ability of local stakeholders and more.

As prior research has identified, a high degree of coordination and collaboration among different stakeholders (both public and private) is one of the main factors for effectiveness and efficacy in destination governance and competitiveness (Del Chiappa and Presenza, 2013). This explains why in tourism literature the term "collaborative destination marketing" was coined (Wang, 2008; Wang and Xiang, 2007). It can be interpreted that in such a 
network, the nature of relationships between public and private organisations are essential for long-term success in tourism and for the development of a successful place brand (Hankinson, 2010).

In the specific context of wine tourism, Getz (2000) argues that vertical and cross-sectorial (vertical and /or lateral) alliances, and networking among different stakeholders (both public and private) is a precondition for a region being successful as a wine tourism destination (Wargenau and Che, 2006). Several studies (for example, Stewart et al., 2008; Wargenau and Che, 2006; Telfer, 2001) argue that augmenting and enhancing collaborations between wineries (horizontal collaborations) and between them, and organisations working in different sectors (vertical and /or lateral collaborations), such as food, hospitality, tour operators, local craft industry and other visitor attractions is fundamental for a destination to be competitive in wine tourism. Similarly, Correia et al. (2004) and Mitchell and Hall (2006) stress that the organisational structure of the wine route is an important factor in its success and that it should involve both public and private organisations. There are those that advise that wineries, local business operators (directly or indirectly tourism-related) and public bodies should jointly analyse visitor needs in order to create a tourism offer able to differentiate itself from that of competitors, thus gaining unique positioning. For example, Marzo-Navarro and Petraja-Iglesias (2012) argue that wineries and public bodies, and broadly the network as a whole, would need to set up external promotion and marketing operations to increase consumers' interest in the wine tourism experience as a precondition to develop a specific tourism offer (Marzo-Navarro and Petraja-Iglesias, 2012).

Both formal and informal agreements between wineries and other tourism-related businesses (accommodation, attractions, etc) and non-tourism related (food industry, handcraft industry) businesses are, or should be, of great importance for the development of wine tourism (Su et al., 1997, Telfer, 2001; Velissariou, et al., 2009). Wine routes are usually characterised by a portfolio of different itineraries and tourism experiences which can be delivered to visitors together with maps (virtual or not) and other promotional materials providing information about wineries, surroundings, natural and cultural attractions, services and facilities that allow them to fully experience the area (Correia, et al., 2004). For this, wine routes should not be viewed as static entities but rather dynamic ones in which visitors can actively choose their own itineraries by selecting the resources that they are more interested in (Brás, et al., 2010).

The aforementioned definitions of wine routes contain at least three different concepts / approaches widely studied by different fields of economic literature (in particular that of regional economics, economic geography and strategic management). Appropriate to this wine network context are the concepts of cluster (Porter, 1990, 1998; Martin and Sunley, 2003; Braun et al., 2005.) and industrial districts (Becattini, 2002), these explain the territorial characterisation of economic development, the concept of strategic inter firm collaborative agreements and the various approaches of regional policy that look at local development as a key element of economic growth. In the case of clusters and districts, economies of agglomeration, especially in the case of Marshallian districts (Marshall, 1920) explain a self-organising process of firms' networking which spontaneously emerges from the confluence of various structural, technological and strategic features.

For the purposes of this study, the wine route is considered as a complex dynamic network of relationships among public and private stakeholders, which cross over organisational boundaries and structures (Rhodes, 1997). It fulfils the aim of assembling all the resources needed to produce the experiences that satisfy visitor needs (Baggio et al., 2010a; Del 
Chiappa and Presenza, 2013), and further, allows consistency of promotions and operations; in order to reach a holistic and effective destination brand positioning (Del Chiappa and Bregoli, 2012). As a consequence the authors concur with prior research, that understanding of wine tourism and wine routes would benefit from a network approach, using both a structural (Brás et al., 2010) and /or a relational perspective (Alonso and Liu, 2012). The structural perspective is based on network analysis and uses quantitative procedures to calculate various indicators to be used to map and to analyse the relationships between stakeholders (Baggio et al., 2010b). The relational approach focuses on analysing the characteristics of interorganisational relationships to assess how these influence the way that different nodes can interact and collaborate with each other, and the roles they play in destination development (Macneil and Campbell, 2001; Saxena, 2005). Recent research suggests that the characteristics of a network of interorganisational relationships should be analysed by using a mixed methodology, combining both the structural and relational perspective, thus enhancing knowledge concerning the way these characteristics can influence the governance and development of their destinations (Del Chiappa and Presenza, 2013).

Despite the benefits that wine routes can generate, in terms of product innovation, scale economies, knowledge transfer and positive externalities (Brás et al., 2010), several barriers to networking in wine routes need to be considered. Mitchell and Schreiber (2006) categorise perceived barriers to vertical integration (for example, wineries perceptions that they are not part of the tourism industry, lack of cohesion between different Regional Tourism Organisations, lack of agreements on who should lead / direct the wine tourism development and so forth), and structural / physical determinants (wineries located away from the main tourist flow and centre of activities, or dispersal over the geographical area etc). Similarly, Hall (2003) provides an extensive list of barriers that prevent effective wine tourism development, among these he suggests to consider poor horizontal and cross-sectoral networking among stakeholders, poor perceptions of wineries concerning the benefits that tourism can produce for the wine industry, a dominant product-oriented marketing, poor skills, abilities and experience in tourism marketing and tourism product development (internal barriers). Further, wine tourism development may be negatively affected by the distance between vineyards and physical / perceived barriers to access, administrative separation from practice, and existence of multiple public administrative agencies within a region (Hall, 2003). With regards to this latter point, it should be noted that wine routes are often spread over different municipalities (Brás, et al., 2010), where different local and regional government administrations may have different approaches and processes. Another issue that affects the degree of success of a tourism destination, concerns the extent of funding available in order that activities can be carried out (Ritchie and Crouch, 2003). Concerning this, Hankinson (2010), for example, argues the necessity to prioritise funds for long-term development (such as the development of a place brand) rather than short-term funds based on membership schemes or political processes. Indeed, in this latter case, an organisation may be seen to focus on short-term objectives aimed at giving returns to their members or political "sponsor" rather than on long-term objectives aimed at the growth of the network.

The lack of leadership to promote both formal and informal cooperative behaviours could negatively affect networking among public and private stakeholders (Hall, 2003). There are a growing number of studies that in the last few years have been devoted to analysing the concept of leadership and its influence on destination competitiveness. This is illustrated by cases of speciality food and drink producers allied to "place", in which the process of 
networking is seen to be initiated and maintained by "leader" firms (Hingley, Lindgreen and Beverland, 2010; Hingley, Boone and Haley, 2010).

The need for leadership is particularly relevant in time of economic turbulence (Pechlaner et al., 2014), when tourism destinations are at the early stage of their life cycle (Zmys 'lony, 2014), and when tourism development in rural areas is considered (Pröbstl-Haider et al., 2014). Specifically, the strong relevance of leadership in rural areas can be explained by the fact that an effective tourism development in such destinations is strongly related to the ability to mobilise the resources and energies of many different sectors (particularly in agriculture, food industry, wine industry and tourism), and to make the most of opportunities to network amongst them (Pröbstl-Haider et al., 2014). When discussing leadership in tourism destination, we need to distinguish between two main forms. On the one hand, it is necessary to consider leadership that occurs within organisations and in inter-organisational relationships, so called transactional and transformational leadership (Valente et al., 2014). On the other hand, we need to consider leadership that occurs at the broader level of the community in which all the stakeholders are involved, thus resulting in so-called systemic leadership. According to Beritelli and Bieger (2013), systemic leadership is concerned with: "the influence of single regions and sectors in wider area or industries, often due to network effects and interdependencies between the relevant units and clusters". This features "actors, actions and influence through personal visions and motivations" (Beritelli and Bieger, 2013, p. 29), and how they help to shape a consensus-based strategy within the tourism destination (Beritelli, 2011). These dimensions of systemic leadership are able to affect the way stakeholders can exert their influence within a tourism destination and can mobilise energies and other stakeholders (Valente et al., 2014) towards the achievement of common goals, namely trust and effective communication (Bieger and Beritelli, 2013).

Businesses belonging to the wine and tourism industry could be considered as communities in which members share the same type of knowledge, skills, language, etc. However, this diversity could also represent an obstacle when the two communities try to interact with each other in a wine route. In this context, the concept of the "boundary object" may be applied, although it has been mainly adopted with regards to innovation processes (Carlile, 2002; Koskinen, 2005; Fox, 2011). Boundary objects are "entities that enhance the capacity of an idea, theory or practice to translate across culturally defined boundaries, for instance between communities of knowledge or practice" (Fox, 2011, p. 71). Boundary objects can be either physical devices or intangible elements such as metaphors that can be understood by people belonging to different groups or organisations, thus creating a shared meaning and allowing learning from each other (Fox, 2011). As a result, boundary objects can be seen as vehicles for passing meanings to different groups and for facilitating collaboration (Sapsed and Salter, 2004; Fox, 2011). According to Carlile (2002), effective boundary objects should possess some characteristics: 1) they should establish a common language that can be used by members of a group or organisation; 2) they should facilitate communication among different people; 3) they should help to develop individual knowledge to assist people in addressing problems (Carlile, 2002). Boundary objects are also interpreted differently by people, for this reason it is necessary that boundary objects are created through discussion. Only in this way it is possible to share the diverse knowledge that each group of individuals possesses and, as a result, consider it whilst developing a boundary object (Koskinen, 2005). Since boundary objects allow transmission of meaning across groups, it has been argued that in their absence different groups struggle to achieve a common understanding, thus resulting in the overall process of innovation being undermined (Koskinen, 2005; Fox, 2011). In this study authors have considered the wine route itself as a boundary object because it is the element that can 
facilitate or hinder collaboration among businesses working in different industries. Thus, by adopting this theoretical lens, the authors present their findings in order to assess the overall research aim of whether businesses were able to develop an effective boundary object (i.e. the wine route). In so doing, addressed also are the consequences that the development of an effective or ineffective boundary object had on the cases studied.

\section{Methodology}

As outlined, our focus concerns the relational perspective of networks and for the purpose of this study qualitative methods (utilising semi-structured interviews with key informants) were chosen; because of the necessity to collect and interpret detailed attitudes of interviewees and allow generation of rich information (Eisenhardt, 1989; Yin, 1994). As such, the method sets out to capture the authentic speech of diverse informants. Interviews were carried out on a sample of stakeholders representing different organisations involved in three different wine routes operating in Italy. Italy was chosen as one of the World's leading wine producing nations with a comparable regional wine structure and identity similar to other wine producing countries. The three wine routes are: the Chianti Classico wine and oil route, in Tuscany; Vermentino of Gallura wine route, in Sardinia; and the food and wine route of Garda, in Lombardy. The wine routes were selected because they are located in different Italian regions characterised by differing levels of development. Specifically, Tuscany has a very strong and established wine identity, while Sardinia is more established as a tourism and agriculture / farming region and has been trying more recently to develop also a wine identity. Finally, Lombardy is an industrial region in which some well known wine areas (such as Franciacorta) coexist with others that are still developing. These differences between the three regions were deemed to be important in allowing understanding of typical similarities and differences among wine routes. This approach could be reflected in potential future application to wine routes of other regions. Furthermore, the focus on Italy was chosen since three of the four members of the research team are Italian, and have strong connections with the three regions, thus allowing access to respondents in areas where regional affiliation is a factor in facilitating engagement with interviewees. Within the wine routes studied the two most important "communities" identified as being critical in terms of working together are represented by wine producers and tourism operators, along with these are also further "communities" represented by local authorities, other service providers such as visitor attractions and other producers (e.g. olive oil producers). A diverse range of informants were interviewed that represent these groups (see Table 1).

\section{$* * *$ TABLE 1 ABOUT HERE $* * *$}

A purposive sampling technique was selected since it allows researchers to select informants that are familiar and have experienced the key concepts being studied (Creswell and Plano Clark, 2010). A snowball sampling procedure was adopted, through which first participants were asked to suggest other people who might be worth contacting for planning an interview (Flick, 2006; Kemper et al., 2003). In this study interviewers contacted first the Presidents of the wine routes and at the end of that interview these were asked to suggest other members of the wine route in order to arrange further interviews. In total 20 interviews were undertaken.

The interviews were carried out by the three Italian researchers who adopted a consistent interview protocol. Questions were developed on the basis of the literature reviewed 
concerning networks and the integration of wine as an integral part of the tourist offer, and specifically addressed four macro-areas (the creation of the wine route, its internal organisation and operation, the relationship between the wine route and the local area, and the future development of the wine route). Table 2 shows the areas under investigation and the questions being asked.

\section{$* * *$ TABLE 2 ABOUT HERE ***}

Questions were first developed in English and once the research team agreed on them, they were translated into Italian and amendments were made until a common agreement was reached. Interviews were carried out in Italian and were arranged by the three researchers, each of which was in charge of a wine route. Each interview lasted from thirty minutes to one hour and was recorded and transcribed verbatim.

Data was analysed through the coding of interview transcripts. In the light of the limited scale of the research, and the fact that it was carried out for the first time, it was decided to analyse data manually, without using any software (Saldaña, 2009). In this approach it is possible to analyse data in creative ways, allowing the researcher to make links to knowledge already present in his / her mind (Saldaña, 2009). Three different coding techniques were adopted: structural coding followed by descriptive coding and pattern coding. Structural coding allowed assigning of codes on the basis of topics predetermined by the researchers. Analysis allowed identification in the transcripts of segments of data that addressed the same topic. These segments were then collected together for further analysis (MacQueen et al., 2008; Saldaña, 2009). In particular, segments were analysed through descriptive coding followed by pattern coding. This latter coding technique was chosen because it is suitable when the researcher wants to study social networks and identify causes and explanations in the data (Miles and Huberman, 1994). The principal investigator conducted the analysis and developed a code book for the team to maintain consistent coding (MacQueen et al., 2008). It was subsequently given to the other Italian members of the team, since the transcripts were written in Italian. They coded independently the transcripts of all interviews and once finished the members of the team met in order to agree on the final codes and, where necessary, to make changes. 


\section{Findings}

An alphanumeric code was given to all interviews and this code was used whilst presenting some of the quotes taken from the interviews (codes are included in Table 1). In this case the first letter identifies the wine route $(\mathrm{C}=$ Chianti; $\mathrm{V}=$ Vermentino; $\mathrm{G}=$ Garda $)$, the second letter identifies the sector in which each interviewee was working $(\mathrm{T}=$ tourism; $\mathrm{W}=$ wine; $\mathrm{C}$ $=$ council; $\mathrm{R}=$ retail; $\mathrm{O}=$ other sectors (for example other agricultural producers), and finally a number identification was given to the interview. Thus, the code GW_01 was given to the first interview made in the Garda wine route to a wine producer. In presenting these findings, the similarities and differences between the wine and the tourism industries are highlighted.

\section{Interpretations of the meaning of wine routes}

According to the literature, boundary objects allow organisations to facilitate collaboration and to transfer a shared meaning across communities (Sapsed and Salter, 2004; Fox, 2011). Considering a wine route as a boundary object means that members of different communities should have a shared understanding on what a wine route is. However, from the interview transcripts of this study, different interpretations of wine routes were identified (see Table 3 ).

\section{$* * *$ TABLE 3 ABOUT HERE $* * *$}

From the table it can be seen that just three informants (all belonging to the wine industry) explicitly considered the wine route as a network of stakeholders (Rhodes, 1997). Another informant (GW_02) acknowledged, in an implicit way, the network nature of a wine route, because he stressed its role in the coordination of stakeholders belonging to different industries. Apart from this, the majority of themes identified were related to the view of a wine route as a project i.e. the wine route represents a means to an end. For instance, the wine route is seen as a way in which to promote the place (thus stressing the strong link existent between the wine route and the place where it is located), and an opportunity to develop the rural economy. Further, some tourism operators linked the wine route to the development of new tourism products that could also help to reduce seasonality of tourism. This view of the wine route as a project was cited by both tourism and wine operators, in contrast to the view that the wine route allows satisfaction of just personal interests, the latter of which was a perspective that was mainly made by wine operators. Indeed, in only one case, a tourism operator (an hotelier) viewed the wine route as a personal opportunity to upgrade hospitality structures. By contrast, various wine operators immediately cited a personal interest whilst talking about the wine route. This could suggest that tourism operators tend to have a broader view on the wine route, while wine operators see it as an opportunity to get an individual benefit, such as an increase in turnover. On this latter point though, it must be pointed out that the three producer respondents who talked about it were wine operators who were criticising the narrow view of other producers. Indeed, all three of them stressed the fact that many people have a mis-perception of what a wine route is. For example, two interviewees argued:

\footnotetext{
"[the wine route] generates benefits over the area as a whole... this is one of the issues on which we struggle the most to communicate, because stakeolders approaching our wine route often want to get immediate return in term of sales [...] and they decide whether to stay in the association or not, based on this aspect." (GW_01)
} 
"The objective of the wine route is not to sell wine; on the contrary that is a limit[ation]! [...] For many the request was to sell wine, but the aim of the wine route is not this, the wine route does not sell any bottle." (VW_01)

From Table 3 it can also be noticed that the theme "promotion of wine" has been considered both in the view that a wine route is a project as well as a self-satisfying tool. This choice was made in consideration of the industry in which the informants were working: in the case of the tourism operator the wine route was viewed as a way to promote the wine of the area so that the overall place could benefit, whilst the wine operator stressed how the wine route can help the promotion of his own wine; thus showing a narrower view of the benefits arising from the wine route. All in all it can be said that operators in the wine and tourism industries agreed with the view that the wine route is a project allowing the achievement of specific objectives, whilst an imbalance exists when the wine route is viewed as a way to achieve individual benefits, and as a network of stakeholders. Both these views were strongly linked to operators in the wine industry.

\section{Consequences of not having a boundary object}

In the cases studied a well defined boundary object (i.e. the wine route) was not identified. As a consequence, it could be argued that this certainly negatively affects the extent to which stakeholders working in different sectors can collaborate, thus compromising the process of information and knowledge sharing across the boundaries existent between the two main communities (wine and tourism). Tourism operators were mainly those who explicitly expressed the need to acquire knowledge on wine, while, on the other hand, wine producers were not expressing a similar concern with regards to tourism-related skills. For example, a tourism operator who was talking about the kind of activities that the wine route should organise, argued:

\section{"Apart from promotion, the wine route should organise some training, because if a visitor comes to me asking for information on the wine and its history, I do not need to be an oenologist, but some training is needed before promoting a} product."(VT_08)

On the contrary, just one of the wine producers stressed the need for stakeholders of the wine route to be more knowledgeable about the overall place and not just about the wine. However, the example used for expressing this idea was still referring to tourism operators and not specifically to wine producers, stating:

\section{"Among our members there is lack of professionalism. One of the limitations of this wine route is the training of members because you can have a member who runs an agri-tourism [business] but he doesn't know anything about wine, about the history of the place, its culture, etc." (VW_01)}

Hence, it appears that tourism operators are considered as the least knowledgeable within the wine route. Another consequence arising from the lack of a clear boundary object is the fact that collaboration between groups struggles to develop (Sapsed and Salter, 2004; Fox, 2011), and this is also due to the lack of an open discussion between members (Koskinen, 2005). For instance, a tourism operator stated: 
“....we seldom meet. We just meet for meetings that are necessary by law such as

the approval of the balance sheet. Apart from these meetings I do not remember any other..." (VT_02)

Hence, no discussion is developed among stakeholders in any form, such as face-to-face meeting or social media that could be used to overcome the problem of geographical distance existent between stakeholders, and the end result is a lack of collaboration. Also the fact that knowledge remains confined within the groups where it is created and circulates, results in the overall collaboration among stakeholders being hindered (Sapsed and Salter, 2004; Koskinen, 2005; Fox, 2011). This idea of knowledge sharing as being important in facilitating collaboration among stakeholders was also stressed by one of the tourism informants, who argued that when he started acquiring knowledge on the local wine, stakeholders from the wine industry changed their attitudes towards him and collaborations started developing:

"The benefit [of joining the wine route] has been of having set up new collaborations, developed more knowledge about local products that before we did not take into account, and meeting people who are doing another job, and that allows you to deepen your knowledge [...]; and I see that on their part there is a bigger consideration towards us that in the past did not exist." (GT_03)

Apart from one case in which one of the informants stated that collaboration among businesses exists, all the other actors (from both industries) agreed that collaboration has not been developed. One of the possible explanations for this was given by one informant, who stressed that stakeholders did not have a strong feeling of being members of the wine route, which probably is due to the fact that they have not clarified between them what the wine route is. A solution to this perceived lack of direction is through the addition of clear leadership in wine routes. As identified earlier, the lack of leadership inherent in such networks (Hingley, Boone and Haley, 2010; Pröbstl-Haider et al., 2014) is a factor behind the lack of comprehension of purpose, direction and cohesion. This can be exemplified by the following quote:

"I never attended meetings of the wine route [...] because I lost any interest in it. Is seems to me that the overall wine route is airy-fairy and I cannot waste my time for things like this wine route [...]. I think that the wine route is not working because members have been put aside, they have never been involved. The President should have met us, discussed with us about problems. In this way we could have sorted out our problems." (VR_10) 


\section{Discussion}

Wine and tourism industries were compared in order to understand whether wine routes can be considered effective boundary objects that bridge the two sectors under investigation, and determine the consequences that an effective or ineffective definition of a wine route can have on knowledge sharing and collaboration among stakeholders. Table 4 shows a summary of the results presented in the previous section.

\section{$* * *$ TABLE 4 ABOUT HERE $* * *$}

It can be immediately seen that the two sectors share similarities when they consider the wine route as a project, whilst the other conceptualisations are only developed within the wine but not in the wider tourism industry. Not even the idea that the wine route is a network is shared by the two sectors and this suggests that, perhaps, the recognition of a network is facilitated among businesses only belonging to the same sector. This finding confirms prior research (Alonso and Liu, 2010; Brás et al., 2010) concerning wine routes, that difficulties typically exist in terms of cohesion and fragmentation among public and private stakeholders and between businesses working in different but related sectors. It could be argued that this poor performance and lack of effectiveness is a consequence of a somehow blurred definition of the wine route, as a not a well-defined boundary object. This leads to a misunderstanding about its scope and goals on the part of the involved stakeholders and affects the degree of collaboration among them. This is despite the fact that collaboration and networking among stakeholders has been considered as a precondition for a wine tourism destination to succeed (Wargenau and Che, 2006). In other words, our findings suggest that the lack of collaboration in wine routes is first, an issue of different perceptions of what a wine route is, and then a problem of trust among the stakeholders.

The fact that the wine route is not a well-defined boundary object results in problems of knowledge sharing. As Table 4 shows, the two sectors under investigation have different perceptions of their knowledge needs, with the members of the tourism sector being the ones that feel the necessity to be trained about wine. Indeed, as some of the literature suggests, boundary objects allow the development of knowledge that is useful for sorting out problems (Carlile, 2002). At the same time it can be said that sharing information and knowledge across sectors is a way to facilitate collaboration among stakeholders, as was exemplified in the case of the hotelier who felt that becoming more knowledgeable on wine allowed him to be considered in a more positive way by the wine producers. The case of the hotelier who is able (thanks to some managerial intervention and training) to improve his knowledge about wine and to share it with customers, thus stimulating them to visit a local winery, can be considered a further example of how a wine route acting as an effective boundary object can enhance knowledge sharing and development; and favour the spontaneous referral of a winery. In other words, it could be argued that sharing knowledge among members of different sectors is a starting point to reduce differences between them and facilitate the development of a shared understanding of the wine route; that in this way can become a proper boundary object. Hence knowledge sharing, on the one hand is a precondition for the wine route to become a boundary object and, on the other hand, it actualises the effective development of a boundary object. As can be seen in Table 4, stakeholders did not believe that collaboration among the two sectors was in place, and this demonstrates the final consequence of not having a shared understanding of what a boundary object is. 
Overall, in order to develop a shared understanding of what a wine route is, it is essential that dialogue among stakeholders develops because otherwise different stakeholders give different meaning to it (Koskinen, 2005). For this reason it is essential that on-line and offline communication spreads (Baggio and Del Chiappa, 2013). In so doing it will be possible to avoid situations in which members of a wine route felt that they had been sidestepped and not involved in the decision making process, as happened with one of the informants.

\section{Managerial implications}

Based on the aforementioned considerations, some useful suggestions that could help to overcome the factors that appear to block the development of the examined wine routes can be provided. First, the public sector (for example, regional and local authorities) should run internal marketing operations in order to harmonise the different stakeholders' views toward what a wine route should be, and then use different coordination mechanisms (Bregoli and Del Chiappa, 2013) aimed at increasing the level of networking and trust among them (Allan, 2011; Brás et al., 2010; Hanna and Rowley, 2011). The public sector should play the role of convener to initiate networking among local stakeholders, and then reduce its involvement over time; thus later becoming 'just' a stakeholder as any other, as strong 'leaders' emerge. This will allow the avoidance of an ineffective top-down strategic approach and taking advantage, as much as possible, of a bottom-up approach (Gnoth, 2002). From an internal marketing point of view, the provision of traditional training among the local stakeholders and the initiation of a quality awards programme to recognise the leaders and best practices could be effective in motivating stakeholders (Stewart et al., 2008). Second, the public partner should provide adequate financial resources to cover the costs of an organisational structure able to supply the minimum services for the management of the initial activities of the wine route. Third, systemic leadership is necessary from, for example, the President of the wine route so that the influence of such specific sectors can be felt in wider area or industries (Beritelli and Bieger, 2013). Indeed, as suggested by Hingley, Lindgreen and Beverland (2010) the success of wine routes is reliant on the quality and dynamism of lead bodies or individuals in which pro-active facilitating leaders may encourage participants to transcend their own interests, for 'the greater good' (Bass and Avolio, 1994). Finally, the wine routes should consider the opportunity to use the internet and social media as both external and internal marketing channels to attract respectively more visitors (Telfer, 2001), and to make the local stakeholders informed about, and involved in the wine route strategy; thus making them committed towards it.

\section{Limitations and future research directions}

Aside from theoretical and managerial contributions, as with all research, the study has limitations. Specifically, it can be considered as being highly site-specific as the study concerned just Italian wine routes. However, results of the study, albeit drawing on limited number of interviews in an Italian wine context, have capacity for generalisation, as they may seem to represent typical cases (Schofield, 2000) of wine routes. Italy does provide many comparable facets of organisation concerning its wine industry, akin to other wine producing countries (for example regional identity, production and quality systems), that interface with tourism and have a strong food culture. Further research, would be useful to replicate the study in other countries (both European and nonEuropean) so that it could be possible, based on a cross-cultural comparison and through the lens of 'boundary object' to devise a more exhaustive framework related to the creation and development of wine routes and or other routes; perhaps of artisanal or 
speciality products that interface with the tourism offer. In addition we recommend benchmarking against successful wine and place success stories, such as that exampled by iconic wine / place exponents of excellence, Champagne, as described in Charters et al. (2013).

\section{Conclusions}

In adopting the theoretical perspective of boundary objects, our findings suggest that research in the area of wine tourism and wine routes might benefit from adopting this approach. Specifically, our findings add knowledge to the current and developing debate concerning integration between the wine and tourism sectors. The main suggestion is that the poor level of collaboration among different stakeholders occurs because they hold different perceptions as to what a wine route is. In our study, local hospitality and wine sectors do not appear to share the same boundary object and do not appear to be working toward a common aim, thus somehow compromising the long-term sustainability of the wine sector and wine tourism.

Attention of policy makers and destination marketers should focus on the need to run internal marketing activities which have the main aim of allowing stakeholders to share the same boundary object. In so doing they could try to persuade stakeholders that a wine route is the expression of a collective effort by different actors belonging to different (but interlinked) sectors to achieve predefined common goals. The fact that just three informants (all belonging to the wine industry) consider the wine route as a network of stakeholders contributes also to the debate around network theory. First, this seems to suggest that the idea of network does not necessarily mirror the way in which some actors would define their sector. Second, it may suggest that the idea of network is more valid where homogenous actors are considered (so that hotels form a network with hotels and not with wineries). Further, our study confirms and contextually provides new evidence and perspectives that explain the reasons why such integration is still difficult to achieve, even in Italy, a country highly appropriate to wine and food tourism. Specifically, our study found lack of confidence, lack of leadership, lack of resources, project discredit and marketing myopia in involving a large number of variously motivated participants, thus resulting in a lack of ability to involve and effectively commit a sufficient number of regional stakeholders. 


\section{References}

Allan, M. (2011), "The leadership challenge", in Morgan, N., Pritchard, A. and Pride, R. (Eds.), Destination Brands: Managing Place Reputation, Butterworth-Heinemann, Oxford, pp. 81-90.

Alonso, A. D. and Liu, Y. (2012), "Old wine region, new concept and sustainable development: winery entrepreneurs' perceived benefits from wine tourism on Spanish Canary Islands", Journal of Sustainable Tourism, Vol. 20, No.7, pp. 991-1009.

Baggio, R. and Del Chiappa, G. (2014), "Real and virtual relationships in tourism digital ecosystems", Information Technology and Tourism, Volume August, Vol. 14, No. 1, pp. 3-19.

Baggio, R., Scott, N., and Cooper, C. (2010a), "Improving tourism destination governance: A complexity science approach", Tourism Review, Vol. 65, No. 4, pp. 51-60.

Baggio, R., Scott, N., and Cooper, C. (2010b), "Network science - a review focused on tourism”, Annals of Tourism Research, Vol. 37, No. 3, pp. 802-827.

Bass, B. M., and Avolio, B. J. (1994), Improving organizational effectiveness through transformational leadership, SAGE, Thousand Oaks.

Becattini, G. (2002), "About the Marshallian industrial district and the theory of the contemporary district. A brief critical reconstruction", Investigaciones Regionales, Vol. 1, pp. 9-32.

Beritelli, P. (2011), "Do actors really agree on strategic issues? Applying consensus analysis of stakeholders perceptions in tourism destination communities", Tourism Analysis, Vol. 16, No. 1, pp. 219-241.

Beritelli, P. and Bieger, T. (2014), "From destination governance to destination leadership defining and exploring the significance with the help of a systemic perspective", Tourism Review, Vol. 69, No. 1, pp. 25 - 46.

Brás, J. M., Costa, C. and Buhalis, D. (2010), "Network analysis and wine routes: The case of the bairrada wine route", The Service Industries Journal, Vol. 30, No. 10, pp. 1621-1641.

Braun, P., McRae-Williams, P., and Lowe, J. (2005), "Small business clustering: Accessing knowledge through local network", paper presented at the CRIC conference Beyond Cluster- Current Practices and Future Strategies, 30 June - 1 July, Ballarat, Australia.

Bregoli, I. and Del Chiappa, G. (2013), "Coordinating relationships among destination stakeholders: evidence from Edinburgh (UK)", Tourism Analysis, Vol. 18, No. 2, pp. 145155 .

Bruwer, J. (2003), "South African wine routes: some perspectives on the wine tourism industry's structural dimensions and wine tourism products", Tourism Management, Vol. 24. No. 4, pp. 423-435.

Bruwer, J. and Johnson, R. (2010), "Placed-based marketing and regional branding strategy perspectives in the California wine industry", Journal of Consumer Marketing, Vol. 27, No. 1, pp. 5-16

Carlile, P. R. (2002), “A pragmatic view of knowledge and boundaries: Boundary objects in new product development”, Organization Science, Vol. 13, No. 4, pp.442-455.

Carlsen, J. (2004), "A review of global wine tourism research", Journal of Wine Research, Vol. 15, No. 1, pp. 5-13. 
Charters, S., Menival, D., Senaux, B. and Serdukov, S. (2013), "Value in the territorial brand: the case of champagne", British Food Journal, Vol. 115, No. 10, pp. 1105-1517.

Coleman, J. S. (1988), "Social capital in the creation of human capital", American Journal of Sociology, Vol. 94, pp. 95-120.

Correia, L., Passos Ascenção, M. J. and Charters, S. M. (2004), "Wine routes in Portugal: A case study of the Bairrada Wine Route", Journal of Wine Research, Vol. 15, No. 1, pp. 1525 .

Creswell, J. W. and Plano Clark, V. L. (2010), Designing and conducting mixed methods research, SAGE, Thousand Oaks.

Del Chiappa, G., and Bregoli, I. (2012), "Destination branding development: Linking together supply-side and demand side perspectives", in Rodoula, H. and Goldsmith, R. E. (Eds.), Strategic marketing in tourism services, Emerald, Bingley, pp. 51-61.

Del Chiappa, G. and Presenza, A. (2013), "The use of network analysis to assess relationships among stakeholders within a tourism destination: An empirical investigation on Costa Smeralda - Gallura, Italy", Tourism Analysis, Vol. 18, No. 1, pp. 1-13.

Dodd, T. (1995), "Opportunities and pitfalls of tourism in a developing wine industry", International Journal of Wine Marketing, Vol. 7, No. 1, pp. 5-16.

Eisenhardt, K.M. (1989), "Building theories from case study research", Academy of Management Review, Vol. 14, No. 4, pp. 532-550.

Flick, U. (2006), An introduction to qualitative research, SAGE, London.

Fox, N. J. (2011), "Boundary objects, social meanings and the success of new technologies", Sociology, Vol. 45, No. 1, pp. 70-85.

Fukuyama F. (1995), Trust, The Free Press, New York.

Getz, D. (2000), Explore wine tourism: Management, development and destinations, Cognizant Communication Corporation, New York.

Gnoth, J. (2002), "Leveraging Export Brands through a Tourism Destination Brand”, Journal of Brand Management, Vol. 9, No. 4-5, pp. 262-280.

Hall, C. M. (2003), "Wine and food tourism networks: a comparative study", in Pavlovich, K. and Akorrie, M. (Eds.), Strategic Alliances and Collaborative Partnerships - A Case Book, Dunmore Press, Palmerston North, pp. 258-268.

Hall, C.M., Johnson, G., and Mitchell, R. (2000), "Wine tourism and regional development", in C.M. Hall, L. Sharples, B. Cambourne, and N. Macionis (Eds.), Wine tourism around the world: Development, management and markets, Butterworth-Heinemann, Oxford, UK, pp. 196-225.

Hall, M. C. and Mitchell, R. (2000), "Wine tourism in the Mediterranean. A tool for restructuring and development", Thunderbird International Business Review, Vol. 42, No. 4, pp. 445-465.

Hall, C. M., Sharples, L., Cambourne, B. and Macionis, N. (2000), Wine tourism around the world: Development, management and markets, Butterworth Heinemann, Oxford.

Hankinson, G. (2010), "Place branding research: A cross-disciplinary agenda and the views of practitioners", Place Branding and Public Diplomacy, Vol. 6, pp. 300-315. 
Hanna, S. and Rowley, J. (2011), "Towards a Strategic Place Brand-Management Model", Journal of Marketing Management, Vol. 27, No. 5-6, pp. 458-476.

Hingley, M., Boone, J., and Haley, S. (2010), "Local food marketing as a development opportunity for small UK agri-food businesses", International Journal on Food System Dynamics, Vol. 3, No. 1, pp. 194-203.

Hingley, M., Lindgreen, A., and Beverland, M. (2010), "Barriers to network innovation in U.K. ethnic fresh produce supply", Entrepreneurship and Regional Development, Vol. 22, No. 1, pp.77-96.

Kemper, E. A., Stringfield, S. and Teddlie, C. (2003), "Mixed methods sampling strategies in social science research", in Tashakkori, A. and Teddlie, C. (Eds.), Handbook of mixed methods research in social \& behavioral research, SAGE, Thousand Oaks, pp. 273-296.

Koskinen, K. U. (2005), "Metaphoric boundary objects as co-ordinating mechanisms in the knowledge sharing of innovation processes", European Journal of Innovation Management, Vol. 8, No. 3, pp. 323-335.

Macneil, I. R., and Campbell, D. (2001), The relational theory of contract: Selected works of Ian Macneil, Sweet \& Maxwell, London.

MacQueen, K. M., McLellan-Lemal, E., Bartholow, K. and Milstein, B. (2008), “Team-based codebook development: Structure, process, and agreement", in Guest, G. and MacQueen, K. M. (Eds.), Handbook for team-based qualitative research, AltaMira Press, Lanham, pp. 119-135.

Marshall, A. (1920), Principles of Economics, MacMillan, London.

Martin, E. and Williams, P. (2003), "Directions in British Columbia wine tourism policy", International Journal of Contemporary Hospitality Management, Vol. 15, No. 6, pp. 317323.

Martin, R., and Sunley, P. (2003), "Deconstructing clusters: chaotic concept or policy panacea", Journal of Economic Geography, Vol. 3, No. 1, pp. 5-35.

Marzo-Navarro, M. and Pedraja-Iglesias, M. (2012), "Critical factor of wine tourism: incentives and barriers from the potential tourists' perspective", International Journal of Contemporary Hospitality Management, Vol. 24, No. 2, pp. 312-334.

Miles, M. B. and Huberman, A. M. (1994), Qualitative data analysis: An expanded sourcebook, Sage, Beverly Hills.

Mitchell, R. and Hall, C.M. (2006), "Wine tourism research: the state of play", Tourism Review International, Vol. 9, pp. 307-32.

Mitchell, R. and Schreiber, M. C. (2006), "Barriers to vertical integration between the wine and tourism industries: the case of Central Otago, New Zealand", in Proceedings of the $3^{\text {rd }}$ International Wine Business Reserach Conference, 6-7-8 July 2006, Montpellier, available at http://academyofwinebusiness.com/wp-content/uploads/2010/05/Mitchell.pdf (accessed 4 September 2014).

Pechlaner, H, Kozack, M. and Volgger, M. (2014), "Destination Leadership: a new paradigm for tourism destinations?", Tourism Review, Vol. 69, No. 1, pp. 1-9.

Porter, M. (1990), The Competitive Advantage of Nations, The Free Press, New York.

Porter, M. (1998), "Clusters and the New Economics of Competition", Harvard Business Review, Vol. 76, No. 6, pp. 77-90. 
Presenza, A. and Del Chiappa, G. (2013), "Entrepreneurial strategies in leveraging food as a tourist resource: a cross-regional analysis in Italy", Journal of Heritage Tourism, Vol. 8, No. 2-3, pp. 182-192.

Pröbstl-Haider, U. Melzer, V. and Jiricka, A. (2014), "Rural tourism opportunities: strategies and requirements for destination leadership in peripheral areas", Tourism Review, Vol. 69, No. 3, pp. 216-228.

Putnam, R.D. (2001), Bowling alone: The collapse and revival of American community, Simon and Schuster, New York.

Ritchie, J. R. B. and Crouch, G. I. (2003), The competitive destination. A sustainable tourism perspective, CABI Publishing, Wallingford.

Rhodes, R. A. W. (1997), Understanding governance: Policy networks, governance, reflexivity and accountability, Open University Press, Buckingham.

Saldaña, J. (2009), The coding manual for qualitative researchers, SAGE, London.

Sapsed, J. and Salter, A. (2004), "Postcards from the edge: Local communities, global programs and boundary objects", Organization Studies, Vol. 25, No. 9, pp. 1515-1534.

Saxena, G. (2005), "Relationships, networks and the learning regions: Case evidence from the Peak District National Park", Tourism Management, Vol. 26, No. 2, pp. 277-289.

Schofield, J. W. (2000), "Increasing the generalizability of qualitative research", in Gomm, R. Hammersley, M. and Foster, P. (Eds.), Case study method: Key issues, key texts, Sage Publications, London, pp. 69-97.

Stewart, J.W, Bramble, L. and Ziraldo, D. (2008), "Key challenges in wine and culinary tourism with practical recommendations", International Journal of Contemporary and Hospitality Management, Vol. 20, No. 3, pp. 302-312.

Su, H. C., Kensinger, J.W., Keown, A. J., and Martin, J. D. (1997), "Do strategic alliances create value?", Journal of Financial Economics, Vol. 46, No. 2, pp. 133-262.

Telfer, D. J, (2001), "Strategic alliances along the Niagara wine route", Tourism Management, Vol. 22, No. 1, pp. 21-30.

Valente, J. V., Dredge, D. and Lohmann, G (2014), "Leadership capacity in two Brazilian regional tourism organizations", Tourism Review, Vol. 69, No. 1, pp. 10-24.

Velissariou, E., Galagala, A. and Karathanos, A. (2009), "Wine tourism. Planning and development of a wine route network in the region of Thessaly in Greece", Tourismos: An International Multidisciplinary Journal of Tourism, Vol. 4, No. 4, pp. 311-330.

Wang, Y. (2008), "Collaborative destination marketing : Understanding the dynamic process", Journal of Travel Research, Vol. 47, No. 2, pp. 151-156.

Wang, Y., and Xiang, Z. (2007), "Toward a theoretical framework of collaborative destination marketing", Journal of Travel Research, Vol. 46, No. 1, pp 5-85.

Wargenau, A. and Che, D. (2006), "Wine tourism development and marketing strategies in Southwest Michigan”, International Journal of Wine Marketing, Vol. 18, No 1, pp. 45-60.

Yin, R.K. (1994), Case Study Research: Design and Methods, 2nd ed., Sage Publications, Thousand Oaks, CA.

Zmys 'lony, P. (2014), Identification of leadership in emerging tourist destinations, Tourism Review, Vol. 69, No. 3, pp. 173-186. 
Tables

Table 1: Summary information about the interviewees

\begin{tabular}{|c|c|c|c|c|c|}
\hline Wine route & Sector & $\begin{array}{l}\text { Type of } \\
\text { organisation }\end{array}$ & $\begin{array}{l}\text { Role in the } \\
\text { organisation }\end{array}$ & $\begin{array}{l}\text { Role in the } \\
\text { wine route }\end{array}$ & Code \\
\hline \multirow{4}{*}{$\begin{array}{l}\text { Food and wine } \\
\text { route of Garda }\end{array}$} & Wine & Winery & Owner & President & GW 01 \\
\hline & Wine & Winery & Owner & Member & GW 02 \\
\hline & Tourism & Hotel & Owner & Member & GT_03 \\
\hline & Other & Olive oil producer & Owner & Member & GO_04 \\
\hline \multirow{11}{*}{$\begin{array}{l}\text { Vermentino of } \\
\text { Gallura wine } \\
\text { route }\end{array}$} & Wine & Winery & Owner & President & VW_01 \\
\hline & Tourism & Wine museum & President & Member & VT_02 \\
\hline & Wine & Winery & Sales manager & Member & VW 03 \\
\hline & Other & Restaurant & Owner & Member & VO_04 \\
\hline & Wine & Winery & Owner & Member & VW_05 \\
\hline & Council & Council & Councillor & Member & $\mathrm{VC} \_06$ \\
\hline & Wine & Wine dealer & Owner & Member & VW 07 \\
\hline & Tourism & Hotel & Owner & Member & VT_08 \\
\hline & Wine & Wine dealer & Owner & Member & VW_09 \\
\hline & Retail & Shop & Owner & Member & VR_10 \\
\hline & Tourism & Tour operator & Owner & Member & VT_11 \\
\hline \multirow{5}{*}{$\begin{array}{l}\text { Chianti Classico } \\
\text { wine and oil } \\
\text { route }\end{array}$} & Wine & Winery & Owner & President & $\mathrm{CW} 01$ \\
\hline & Wine & Winery & Owner & Member & CW_02 \\
\hline & Wine & Winery & Owner & Member & CW_03 \\
\hline & Wine & Winery & Owner & Member & $\mathrm{CW} \quad 04$ \\
\hline & Council & Council & Councillor & Member & CC_05 \\
\hline
\end{tabular}


Table 2: Topics investigated and questions asked in the interviews

\begin{tabular}{|c|c|}
\hline Topics investigated & Questions being asked \\
\hline \multirow{6}{*}{$\begin{array}{l}\text { Wine route development and } \\
\text { interviewee's personal } \\
\text { involvement }\end{array}$} & Why did you decide to become involved in a wine route? \\
\hline & When was it set up? \\
\hline & How was it set up? \\
\hline & Who led its development? \\
\hline & What value do you get from being involved in the wine route? \\
\hline & $\begin{array}{l}\text { Do you believe that there is equal commitment from participants and } \\
\text { benefits to them in the wine route? }\end{array}$ \\
\hline \multirow{6}{*}{$\begin{array}{l}\text { Organisation and operation of } \\
\text { the wine route }\end{array}$} & What is the general organisation of the wine route? \\
\hline & What are the rules for joining the wine route? \\
\hline & How are decisions taken? \\
\hline & How do members interact in the wine route? \\
\hline & Do you use any ICTs and social media platforms? \\
\hline & $\begin{array}{l}\text { Is there any collaboration between businesses of the different } \\
\text { industries }\end{array}$ \\
\hline \multirow{4}{*}{$\begin{array}{l}\text { Wine route and the promotion } \\
\text { of the local area }\end{array}$} & $\begin{array}{l}\text { Can you provide examples of the kind of activities involved in the } \\
\text { wine route? }\end{array}$ \\
\hline & What are the most important aspects of the identity of the region? \\
\hline & Is the wine route promoting the destination/local area? \\
\hline & $\begin{array}{l}\text { What are the best and worst aspects concerning the role of the wine } \\
\text { route in the promotion of the local area? }\end{array}$ \\
\hline \multirow{3}{*}{$\begin{array}{l}\text { Improvements of the wine } \\
\text { route }\end{array}$} & $\begin{array}{l}\text { What are the issues that you have encountered in setting up, } \\
\text { developing and managing the wine route? }\end{array}$ \\
\hline & What could be done to improve the wine route? \\
\hline & What do you believe the future of the wine route will be? \\
\hline
\end{tabular}

